\title{
Using Geographic Information Systems in science classrooms
}

\section{Usando o Sistema de Informação Geográfica (GIS) em salas de aula de ciências}

\author{
Diane Whitaker ${ }^{1}$
}

\begin{abstract}
This qualitative study examines GIS use in two North Carolina classrooms and illustrates several GIS lessons that span the gamut of worksheet type lessons to independent student research. Using Geographic Information Systems, GIS, in the science classroom has a variety of benefits which the associated literature describes. The teachers in this study report that GIS is a technology that a wide range of students enjoy using. Visual learners find GIS a way to establish and communicate relationships that may be difficult for them to communicate with words and this makes their learning more enjoyable and rewarding. GIS use allows teachers to simplify many science concepts and again appeal to visual learners. Earthquake and volcano location relative to plate boundaries is a good example that is illustrated in a model lesson here. Additionally, GIS technologies allow students to practice and enhance their inquiry and problem solving skills. Students must select appropriate data layers, produce a map that communicates clearly to an audience, and calculate values like perimeter and area. GIS maps can be used to help students generate research questions and then answer those questions. An example student project is also included. GIS is a multi-faceted technology that is ready for use in the science curriculum.
\end{abstract} Key Words: GIS; science education; implementation; lessons.

1 Professora de Geociências do Colégio de Ensino Médio Southwest Guilford, em Greensboro, NC, EUA. E-mail: dcwhitak@unity.ncsu.edu 


\section{RESUMO}

Este estudo qualitativo examina o uso do GIS em duas salas de aula da Carolina do Norte, EUA e ilustra uma gama de atividades realizadas para promover pesquisas independentes entre os estudantes. O uso do GIS na sala de aula de ciências possui vários benefícios descritos na literatura. Neste estudo os professores relataram que o GIS é uma tecnologia que os estudantes gostam de usar. Aprendizes visuais acham que o GIS é uma forma de estabelecer relações que podem ser difíceis de explicar com palavras, assim a aprendizagem deles é mais proveitosa e compensadora. O GIS permite ao professor simplificar muitos conceitos científicos. A localização de terremotos, vulcões e a relação com os limites das placas tectônicas é um exemplo do que foi usado em uma aula. Além disso, as tecnologias de GIS permitem que os estudantes pratiquem e melhorem suas habilidades de investigação e de resolução de problemas. Os estudantes selecionam várias camadas de dados para produzir mapas que comuniquem claramente, além de fazer cálculos como os de perímetros de área. Os mapas GIS podem ser vistos como uma tecnologia multifacetada pronta para o uso em currículos e ciências.

Palavras-chave: GIS; educação em ciência; implementação; lições.

\section{Background of the study}

As the tools for collecting environmental data have shifted to computerized field data collection devices, aerial photography, and real-time remotely sensed ground and satellite monitoring the need to manage, store, and analyze the vast amount of data has necessitated a new approach to environmental research. That approach is Geographic Information Systems or GIS. GIS is a suitable data management tool anytime data can be tied to particular places on the Earth. Much like graphing data on X and Y coordinate system, GIS links descriptive data gathered in the field to an $\mathrm{X}, \mathrm{Y}$ coordinate displayed on a map. GIS uses include emergency management fire and police dispatch, bus routing, and wildlife management. The educational applications are of interest here, especially applications to science content in middle school through high school.

GIS software is the tool that sets the stage for teachers to use GIS to build inquiry, "hands-on, minds-on" lessons and projects that are correlated to specific content objectives. 


\section{Purpose of the study}

The purpose of this study is twofold: 1) to determine how and why teachers use Geographic Information Systems in their classrooms and 2) to identify a variety of successful student activities in GIS. GIS is a relatively new technology that is filtering in to the classroom. It is important to understand how and why teachers use GIS in the classroom to facilitate future use, lesson design and implementation, and plan teacher training. In examining teacher use of GIS it is also just as important to determine what is preventing teachers from using GIS.

To investigate how teachers use GIS and why they use the tool this study will address several areas of teacher perceptions. The specific questions are: 1) Why did teachers decide to use GIS as a teaching tool? 2) How is GIS being implemented in the classroom? and 3) What do teachers perceive as barriers to GIS implementation?

\section{GIS literature review}

Geographic Information Science, (GIS) is both a technology and spatial data analysis tool used by professionals and educators. As educational uses of GIS grow, it is important to identify how and why the technology and its use in the classroom may enhance both content achievement and spatial thinking skills. Research assessing under what set of conditions GIS use has maximum student benefit and under what conditions its use may prove detrimental to student learning is also worth investigating. A discussion of current GIS use and its benefits and barriers to classroom use will be discussed.

The use of GIS in classrooms and the benefits reaped from its use may be partially explained by current learning theory. Researchers have noted that GIS lessons make learning meaningful to students, fitting well with a constructivist environment (KEIPER, 1999). When Kerski (2000) reviewed GIS lessons currently being taught, he noted that the lessons were constructivist, reformist, and interdisciplinary in nature. When using GIS lessons, students are more apt to activate prior knowledge and relate personal experiences to their classroom instruction, which enables them to form new mental models of science concepts (Walker, 2004). Broda and Baxter (2003) have documented that teenagers shift back and forth between concrete and formal operations, and GIS activities can 
accommodate those shifts allowing students to process information visually, manipulate information mathematically, and also interpret and synthesize that information while using it to predict outcomes and develop relationships. Broda and Baxter also note that GIS illustrates Gardner's multiple intelligence theory. They note that linguistic, logical/mathematical, spatial, and interpersonal intelligences can be incorporated into GIS activities (BRODA; BAXTER, 2003). They also make the case that GIS activities address Gardner's eighth intelligence, the naturalist, who is adept at finding patterns in nature.

GIS, as a teaching tool, is supported by constructivist learning theory. As students generate data, and through their own analysis, construct meaning for the data while connecting it to a specific geographic location, we need to examine what spatial thinking skills are employed and how students make use of the spatial thinking skills required for implementing GIS computer mapping and spatial analysis technology. Goodchild and Kemp (1990) state four reasons for the addition of GIS to the high school curriculum. First, the technology, (software and adequate hardware) is becoming more widely used in a diverse set of industries. Second, it is a tool of choice for environmental analysis and problem solving. Third, it enhances student interest in technology and geography, and finally it exposes students to a technology related career. Keiper (1999) supports Goodchild and Kemp's (1990), reasoning by suggesting that GIS be used in authentic settings and in a variety of content areas where students can collect and generate data that are real and pertinent to their daily life. These activities model the daily routine of an environmental analyst and again parallel the constructivist theory of learning.

When we examine who is actually using GIS in the classroom, the results are surprising. Kerski (2000) found that "Only 20\% of teachers using GIS use it more than one lesson in more than one class." (p.132) He found that veteran science teachers, particularly chemistry teachers, not geography teachers, were the most represented teacher group. Furthermore, the typical GIS school is a standard-sized. When Audet and Paris (1997) evaluated the reasons teachers use GIS they found a variety of reasons that also reflected the constructivist learning theory and spatial thinking skills discussed earlier. Teachers reported to Audet and Paris that GIS can "...swiftly and dynamically represent the world and its issues from a variety of spatial perspectives.” (AUDET; PARIS, 1997, p.298) GIS not only expands the scope of topics students can explore, it is highly interdisciplinary. Teachers report that using GIS changes the way that students learn to reason about the relationship of data to a particular geographic space. Space may be considered two-dimensional or three dimensional as latitude, longitude and elevation are all variables consistent with GIS use. When implementing GIS, teachers report that their classroom atmosphere is more student-centered 
with more problem-based activities being incorporated into lessons. Teachers believe that GIS (a) enhances problem solving, (b) enables spatial data analysis and (c) increases enjoyment for students. Audet and Paris (1997) observed that teachers who incorporate GIS into lessons seem less concerned about transmitting information than guiding student discovery which again supports the constructivist theory of learning.

When students use GIS technology it facilitates student learning and changes the learning environment. A number of educators have reported distinct benefits with the use of GIS technology. Specifically, Mackaness (1994) has reported that GIS use broadens the scope of the classroom and improves the quality of learning. Several researchers have found that GIS use is a powerful aid to three-dimensional visualization, problem solving, and spatial understanding and encourages creative thinking (WINN; MAGGIO; WUNNEBURGER, 1996; ROONEY; DOUBLER; PAGET, 1998). An empirical study conducted in Boulder, Colorado used a case study to assess the effectiveness of GIS and found that students working with GIS increased their use of maps as analytical tools supporting the non-research substantiated thoughts and comments of other teachers (Wanner, 1999). In a similar study, GIS has been shown to improve integrated science process skills, especially data analysis skills (BAKER; WHITE, 2003). In a direct comparison of teaching methods, GIS versus traditional method, students using GIS scored significantly higher than students using traditional methods on four out of nine tests. The students in the GIS group also demonstrated a better ability to synthesize, identify and describe reasons for patterns (KERSKI, 2000). Kerski summarizes his research by stating, "Implementing GIS alters the manner of learning." (KERSKI, 2000, p.112)

In addition to Kerski other researchers have been able to document a number of student benefits in the area of problem solving when GIS is employed as a teaching strategy. Research has documented that students are better able to visualize complex relationships after using GIS and visualization has been demonstrated to be a very powerful tool in understanding problems and finding solutions (BRODA; BAXTER, 2003). "The ability to create visualizations and spatial queries makes GIS a powerful tool for students, both in solving problems and engaging their minds." (BRODA; BAXTER, 2003, p.159). In terms of spatial thinking, GIS provides a much broader range of scales than standard classroom methods (West, 2003) GIS has been found to foster curiosity and a sense of idealism for students (BRODA; BAXTER, 2003). Using GIS allows students to manipulate much larger volumes of data and a wide range of real-world data that can describe both cultural settings and environmental settings. GIS can aid in-depth analysis allowing students to analyze and evaluate data, which fosters complex cognitive activities. These documented student benefits 
provide evidence that GIS is a useful tool and teaching strategy over a broad range of curricular applications. To this point however, there is a mixed review of the effectiveness of GIS classroom use and its impact on achievement (KERSKI, 2000).

GIS use may affect more than just thinking skills and student achievement; it may also increase student engagement. Several studies have shown an increase in student motivation and attitude because GIS increases relevance and encourages more focused thought (WEST, 2003). GIS empowers students to solve problems independently and to use computers as a professional tool. GIS encourages better resolution of issues and a feeling of greater success, which translates into greater intrinsic motivation (WEST, 2003). GIS investigations were found to illicit a positive and significant change in self-efficacy scores and technology attitudes and students reported higher attitudes towards making personal decisions based on scientific data (BAKER; WHITE, 2003). These findings describe skills and attitudes that are deemed important by educators and scientists and are supported by constructivist learning theory. In preparation for twenty-first century jobs, students were observed acting like managers of a data project with appropriate workplace skills (WANNER; KERSKI, 2003). Students were observed taking ownership of projects with GIS components (WANNER; KERSKI, 2003). As an interesting note on student engagement, one study found that GIS might benefit students with lower skills more than those with higher skills (WANNER; KERSKI, 2003).

As beneficial as GIS may be as a teaching tool there are barriers to its implementation. The first barrier is time-the time it takes to implement the technology and the time it takes to develop lessons. Teachers must attend workshops, develop their computer skills and then develop lessons appropriate to their individual classes (MEYER; BUTTERICK; ZACH, 1999). The lack of teacher training and the complexity of the software compounds the time needed for GIS implementation (KERSKI, 2000). A second barrier is the lack of sufficient computer resources (KERSKI, 2000). Software installation requires adequate computer processing speed and memory. Often education administrators are unwilling to partition the server space needed for the GIS software or to assign technology staff to maintain GIS files and serve as a help desk (WALKER, 2004). Kerski (2000) noted however, that the time barrier is a more significant barrier than the technology barrier. We are reminded of the technological immigrant versus the technological native. Students adapt to and learn technology-based skills far faster and with greater ease than their teachers.

Incorporating GIS into the science classroom has multiple benefits. Its use is supported by constructivist learning theory that encourages and supports an interdisciplinary and multicultural approach to learning. Student attitudes 
towards science improve when GIS is used as a teaching strategy. As a strategy, GIS lessons encourage higher order thinking and science processing skills such as analysis, synthesis and application at the same time it increases student engagement and a willingness to take ownership of a data driven project. GIS lessons can mimic the real world of an environmental scientist or city planner. The major barrier to the implementation of GIS is summed up by Wanner $(1999$, p. 4),

Concrete evidence of the effectiveness of geographic information systems in the curriculum is lacking. Research concerning the effectiveness of GIS technology and methods has been confined chiefly to anecdotal evidence from classroom observation.

As a number of researchers have pointed out, there is a deficit in quality GIS research. A good deal of what has been presented here would be considered anecdotal evidence. Bednarz and Ludwig (1997) suggested a research action agenda for educators that included investigations on the current status of GIS in K-12 education, informing those with power and authority to make changes about the need for GIS, the best way to provide teachers and pre-service methods instructors with support and materials for teaching GIS, the effect of GIS on human cognition and learning, and the best way to reform pre-service education to include GIS. In one of the more comprehensive research studies, Kerski (2000), presented findings in his dissertation and related journal articles of a single study consisting of two classroom case studies. In agreement with Bednarz and Ludwig (1997), Kerski found that little work has been completed to determine what teachers think about implementing GIS into the curriculum, what problems they have experienced implementing GIS into the curriculum, and who should be responsible for seeing that GIS implementation takes place. It is the intention that the research presented here will provide a clearer picture of how GIS is being used in North Carolina classrooms, why teachers are using the technology, what teachers consider to be barriers to implication of GIS use, and who teachers feel are responsible for successful GIS implementation. 


\section{Methodology}

The purpose of this project is to ascertain how and why teachers use GIS in their classrooms. Since the use of GIS would be considered a single subject the case study methodology of qualitative research was employed. Two teachers were interviewed using a semi-structured interview style and the interviews were transcribed and coded. Information gleaned from the interviews was triangulated with documents from the teachers' schools, department of public instruction, curriculum materials, and student work records.

By selecting a case study approach for this project, the researcher must make some assumptions. First, it is assumed the interview questions will illicit the information necessary to answer the research questions. Follow-up questions will be used to refine information, gather more specific information, and clarify thoughts and opinions. A second assumption is that the teachers interviewed are telling the truth and giving accurate accounts of their feelings and opinions. Third, the researcher assumed that the teachers interviewed are in "typical" teaching situations, representative of a majority of classes across North Carolina that use GIS as a teaching strategy.

The subjects in this study were selected from participants in GIS workshops sponsored by North Carolina State University College of Natural Resources and SciLink. Teachers in private and public school settings were included in the sampling frame. Three teachers became the subjects for the study. Two of the interviews were scheduled as face-to-face interviews at the subject's schools and the third was a phone interview as the subject had moved to Tennessee. One of the local study subjects canceled his interview twice. It was not rescheduled the third time due to deadlines and time constraints. The final sample was two teachers.

Both of the subjects in the study are Caucasian females with more than fifteen years of teaching experience in both elementary and secondary grades. Both have undergraduate and advanced degrees with academic backgrounds life science. The two subjects fit the profile of the "typical" teacher using GIS illustrated in the literature by Kerski (2000). Both subjects also held leadership positions within their educational settings. They served as chairs of committees, grade level chairs, and conducted extracurricular activities for students. Importantly, both teachers continue their personal education by attending workshops and classes outside of school.

Lynn was the first subject interviewed. The interview was held in her room immediately after school. She works in a technology magnet middle school that 
draws its population from an urban county in central North Carolina. The middle school is associated with a state supported university and is actually located on the engineering campus. The school has a very diverse population of students ethnically and economically who are drawn from across the county. Lynn said that the distance some students have to travel can be a negative aspect of the school. Some children travel over an hour and a half each way on a school bus to get to and from school each day.

Lynn's room had many examples of student work displayed, posters of scientists actively doing science, and illustrations of the scientific processes the students were studying. Lynn explained that the school is in the first year of being a lap top school. Each student and teacher is given a laptop computer, which is supposed to serve as a student locker for content information and text materials; a notebook for composing, submitting, and archiving assignments; and a communications tool for presentations and staying in touch with the teacher and classmates. Lynn was insistent that her students be actively engaged in science and models as closely as possible what scientists do in the real world. These were reasons she gave for incorporating GIS into the curriculum.

Joanne, the second subject, was interviewed by phone as she had moved out of state since completing the GIS workshops. Joanne was a middle school science teacher also at a science and technology magnet school. Unlike Lynn's setting however, Joanne's school is set in the oldest public housing project in the city. The school has a long history of which the residents are very proud. A large number of its graduates went on to become politicians, very successful business owners, and professionals in many arenas. Joanne was instrumental in designing and implementing a technology and GIS course for the school that used satellite imagery and GIS as its subject matter.

Joanne also pursued a doctorate degree in science education and forestry in which GIS was a large segment of her class work. Consequently, after she finished her class work and GIS workshops she began to instruct the workshops. Joanne decided to investigate the relationship between GIS usage and spatial thinking skills as her dissertation topic. She has presented many sessions at state and national meetings concerning GIS and its implementation and has served on and chaired many state wide GIS committees concerned with educational applications of GIS.

The case study methodology employed in this study made use of a semistructured interview and the work of Bednarz and Ludwig (1997), served as the foundation of the survey. The researcher wrote a survey of fourteen questions that could be compartmentalized into four sections, three of which were suggested by the research of Bednarz and Ludwig (1997). The first question was simply to find out what the subjects were currently teaching and what their work related 
responsibilities were. Questions two through four were about GIS training-a description of how the subjects were trained, when they were trained, and why they were trained. Questions five through seven addressed GIS implementation and sought to identify how the subjects were implementing GIS in their classroom. Questions eight through fourteen looked at barriers to GIS implementation and asked about specific factors preventing teachers from implementing GIS and who should be responsible for mitigating those factors. At the end of the survey the teachers were asked if they had any additional comments or examples that they would like to share. In general, the survey took about an hour to complete. Neither subject had any difficulty answering and giving classroom examples addressing the survey questions.

\section{Data analysis}

Both interviews were transcribed verbatim. Field notes taken at the time of the interview added insight into the feelings of the subjects and were combined with the transcripts to glean a clearer picture of what the subjects truly meant. Transcripts were coded to identify the themes in GIS training, implementation, and barriers to implementation. A color-coding system was employed to analyze the interview data. The questions were broken down into three blocks: questions two through four dealt with the GIS training, questions five through seven dealt with the implementation of GIS, and questions eight through thirteen addressed perceived barriers to GIS implementation. Question one was not coded as it was biographical information about the subjects. Question fourteen was a free response and coded separately for any of the three major themes of training, implementation, or barriers to implementation. After the common ideas were color- coded they were grouped into emerging themes and recorded in a matrix.

\section{Validity, reliability, and limitations}

The validity of this study is complimented by the fact that the instrument used to gather data was tied to GIS research. The questions on the survey were derived from a literature review and recommendations made to higher education institutions as areas for further investigation. The subjects that were selected 
fit what the research defined as the typical teacher that uses GIS. While the subjects selected for this study increase reliability, the fact that there were only two participants, with little diversity in ethnicity, age, experience, and training decreases the generalizability of the study.

The major limitations of this study are the sample selection and sample size. The sampling reference was selected from only one type of workshop participant, those people that completed week-long workshops on a university campus. This selection narrowed the subject pool geographically to teachers within a relatively short driving distance of the workshop location. An additional limitation is both subjects are Caucasian. There was a decided lack of ethnic diversity in the sampling frame. Drawing conclusions based on two people who are very similar in experience and training decreases the generalizability of the study considerably.

\section{Preliminary findings}

The interview guide for this study was designed so that there are several survey questions that address each of the three research questions. Biographical information indicated that both subjects began their training in 1995 at a one -week workshop offered by the school system in which they taught. Lynn and Joanne both chose to take additional workshops sponsored and taught by the same university group. Where they differ is that Joanne chose to supplement the workshop training with the GIS certificate courses offered by the university. Lynn stated, "... had I been younger I would have gone on to do the certification."

When both women were asked what lead them to seek GIS training their answers were similar. Lynn emphasized the importance of geography and mapping to understanding science and remarked about the ease of using GIS for data analysis. Joanne was quick to say that she embraced GIS training because of the ability to do scientific modeling. She had been looking for ways to incorporate modeling into her classroom but what she found was far too complicated for middle school students. Both of them admitted that once they tried the program they were "hooked". Twelve years later, both participants are still employing GIS as a teaching strategy.

For the first research question, which was concerned with why the teachers decided to implement GIS in their classrooms, both respondents were quick with answers when asked about what factors of GIS make it a teaching tool they want to include in the classroom. Lynn immediately responded that, "Relevance is 
number 1. Timeliness is number 2." Both teachers commented about the ease with which students can visualize data using GIS. They both made reference to people being visual learners and once a concept can be visualized it can be understood. Research findings reported by Broda and Baxter (2003) parallel what was stated in this study saying that after using GIS students are better able to visualize complex relationships. Lynn emphasized using GIS as a strategy because it promotes inquiry and Joanne because it promotes modeling. Lynn also pointed out that GIS use would be considered a " $21^{\text {st }}$ century tool", tools that students will be able to carry forward in their educational experience. Joanne commented that the immediacy of GIS as tool matches students needs; with the click of a mouse changes are made and analyses completed.

Joanne said her students thought GIS was "cool" and "fun". Lynn commented that rarely did she observe a child off task when using GIS as a strategy. When Lynn was asked why she thought that this was the case, she replied that students need to investigate problems that they don't have answers to beforehand. This echoes what Joanne said about using GIS for inquiry. These results enhance and supplement the findings reported by Wanner and Kerski (2003), Walker (2004), and Broda and Baxter (2003).

The second research question investigates how the two teachers employ GIS in their classrooms. Lynn said she often prepared map handouts for her students. Figure 1 illustrates such a map.

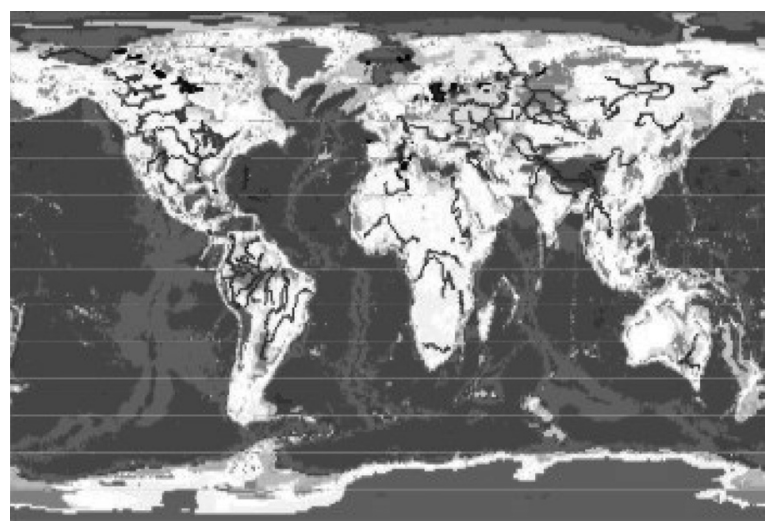

Figure 1 - World Elevation Map Prepared from ArcVoyager Data 
The first example both teachers gave as a lesson was one they use in the unit on volcanoes, earthquakes, and plate tectonics. They both reported how much easier it is for students to glean the relationship among earthquakes, volcanoes, and plate boundaries when maps of the three features are over laid upon each other. This is a great example of the visual analysis capability of GIS. To teach this concept, both teachers use an ArcVoyager lesson that is downloadable from the ESRI website. The teachers feel that the lesson is straight forward, well written, and can be modified easily to meet individual teacher needs. Learning objectives are clearly stated and all the necessary data can be downloaded from the web. Below is a sample map that students generated.

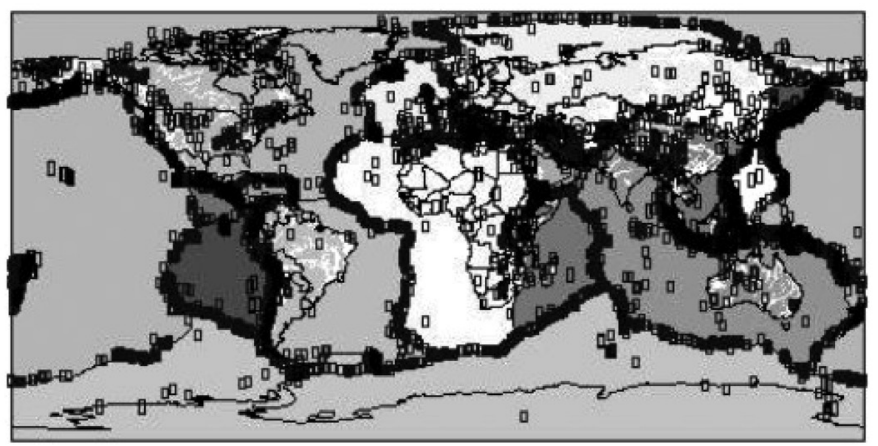

Figure 2 - Volcanoes, Earthquake, and Plate Boundaries Map From ArcVoyager Lesson

Both teachers use GIS for project-based learning also. In fact, Joanne made note that in planning lessons she always asked herself, "Can GIS do this better?" If the answer was yes, she planned accordingly. Lynn took a traditional study site ecology lesson and turned it into a GIS lesson so that information from the study site could be stored, visualized, and used by future classes. What was once a simple inquiry lesson became a longitudinal, scientific investigation. A third teacher, not interviewed in the study, contributed two examples of project based GIS lessons. The first example is of an on-going class project on water quality conducted on a river close to the school that feeds the local drinking water reservoir. Students collect data monthly, add it to a data base, and then update results. 

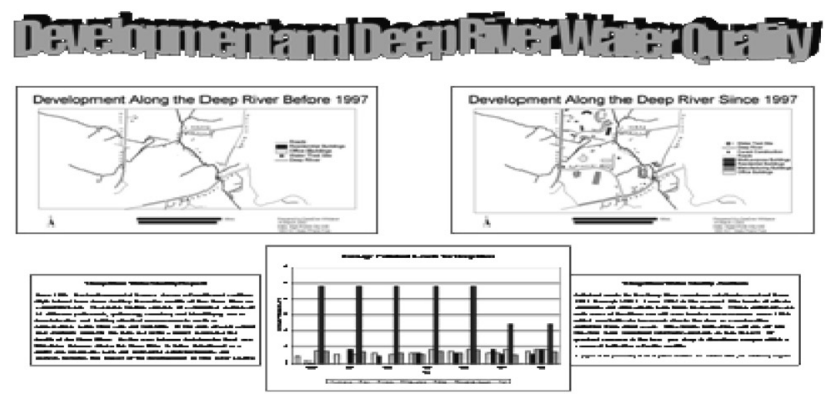

Figure 3 - Deep River Water Quality

Increasing the level of inquiry from teacher directed lessons to student directed, independent research is illustrated in the last example of a GIS project. Over a three month period a single student investigated the relationship between rainfall and pollution in a suburban retention pond. Data was collected, analyzed, and linked to a GIS map of the area.

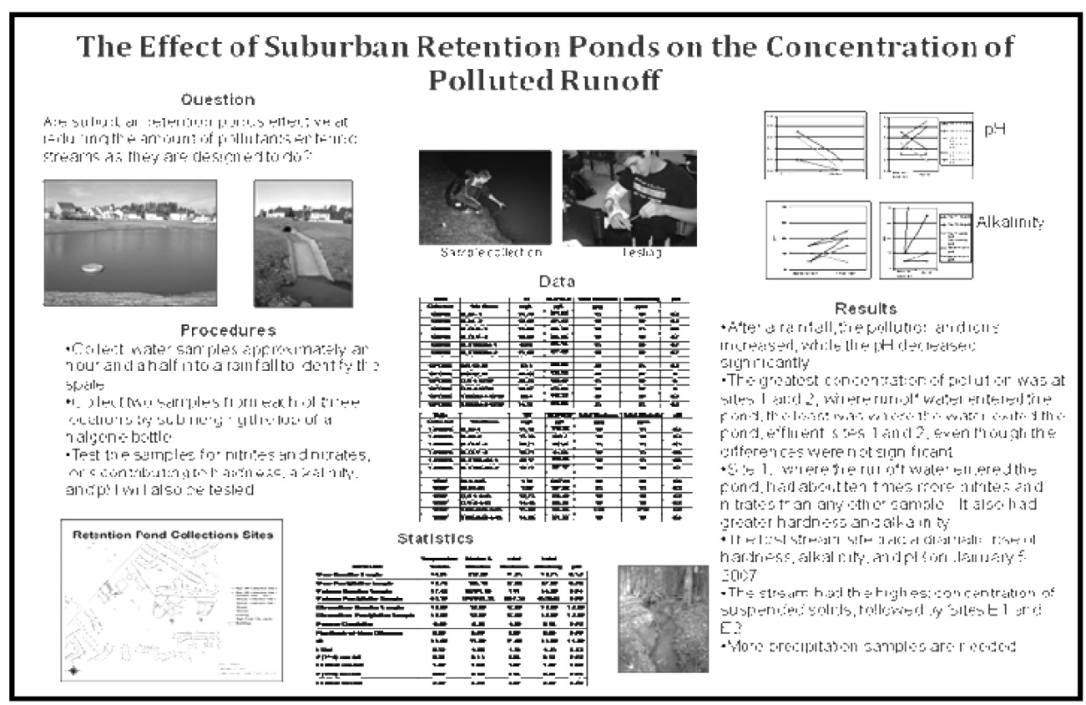

Figure 4: Independent Student research Project 
The third research question to be addressed is that of the perceived barriers to implementing GIS which fell into two categories: barriers and needs. Barriers are considered items that would totally prevent teachers from incorporating GIS into a lesson while needs would make incorporating lessons harder. Lynn listed the first barrier as a standardized pacing guide. The guide dictates the content, order, and duration for the entire course. Lynn mentioned that she normally would start the year with a GIS skills unit so she could slip in lessons throughout the year but the pacing guide makes this impossible. The standardized pacing guide only allows five days for technological applications of all types. Both Lynn and Joanne stated that the pressure to prepare students for standardized end of grade exams makes any type of "...creative or cutting edge science" impossible. Another barrier, related to the ones above is that GIS use is not explicitly stated in the North Carolina Standard Course of Study. In the eighth grade curriculum, mapping and data technology tools are mentioned but not specifically GIS. The subjects listed cost, hardware memory, teacher computer skills, appropriate and available lessons, and teacher training as non-barriers.

Both teachers agree that there is a lengthy list of needs that would facilitate GIS implementation but none of which prevent the use of GIS. The first need is the time to find and retrieve appropriate data sets. Lynn and Joanne suggested that at the state level there be a GIS data base correlated to objectives, not just for science but also for math and social studies. They both also stressed the importance of teacher support for curriculum and technology. Workshops that continue and advance GIS knowledge and skills are also needed as the software continues to change.

Both subjects stated that "Administrators" should be responsible for making the needed changes to facilitate GIS use. Lynn specifically said science supervisors and building principals while Joann said federal level researchers. It appears that the impediments to GIS use are the imposed structure, content, and pacing necessitated by standardized testing and lack of teacher support for planning, curriculum development, and technology support.

\section{Conclusions and implications}

Upon looking at the literature, interview transcripts, and archived documents there appears to be two encompassing conclusions. First, students found GIS lessons very enjoyable and the lessons kept students on task. Joanne mentioned the importance GIS plays as a method of scientific modeling. Both 
teachers felt the most important feature of GIS as a teaching strategy is its ability to allow students to visualize data. They said their students learn visually and being able to visualize complex concepts made a large difference in students' ability to understand science. The teachers primarily used GIS in conjunction with student projects and not as daily lessons.

Second, both teachers in this study reported support for teachers integrating GIS, both instructional and technological, as the biggest barrier. Joanne even went so far as to say the barriers listed in the literature were definitely not barriers any longer. When the participants were asked who should be responsible for seeing that GIS is implemented broadly across the curriculum, they both said administrators from the central office content supervisory level to federal curriculum mandates. Since these two findings are atypical compared to the literature, they merit further investigation. Study participants mentioned how important it is to have GIS written into the curriculum which was an unintended outcome. Curriculum policy, like technology policy could be written from the local to federal level. What was not addressed in the GIS literature or in this study was if there is a relationship between GIS being included in a curriculum or standard course of study and whether or not it is actually implemented in the classroom. To date, we know teachers use GIS as a tool for student projects and as stand-alone lessons. We don't know whether incorporating GIS into a standard course of study increases the number of teachers using GIS or the number of lessons taught using GIS. This topic necessitates future research.

\section{REFERENCES}

ALIBRANDI, M. GIS as a tool in interdisciplinary environmental studies: Student, teacher, and community perspectives. Meridian, v. 1, n. 2, 1998.

AUDET, R. H.; ABEGG, G. L. Geographic Information Systems: Implications for problem solving. Journal of Research in Science Teaching, v. 33, n. 1, p. 21-45, 1997.

AUDET, R. H.; PARIS, J. GIS implementation model for schools: Assessing the critical concerns. Journal of Geography, v. 96, n. 6, p. 293-300, 1997.

BAKER, T.; WHITE, S. The effects of G.I.S. on students' attitudes, self-efficacy and achievement in middle school science classrooms. Journal of Geography, v. 102, n. 6 , p. 243-254, 2003. 
BEDNARZ, S.; LUDWIG, G. Ten things higher education needs to know about GIS in primary and secondary education. Transactions in GIS, v. 2, n. 2, p. 123-133, 1997.

BRODA, H.; BAXTER, R. Using GIS and GPS technology as an instructional tool. The Social Studies, v. 94, n. 4, p. 158-160, 2003.

ESRI. ArcVoyager. 2011. Disponível em: <http://edcommunity.esri.com/arclessons/ lesson.cfm?id=19>. Acesso em: 2000.

GOODCHILD, M.; KEMP, K. The NCGIA core curriculum in GIS National Center for Geographic Information and Analysis. University of California, Santa Barbara, CA, 1990.

KEIPER, T. A. GIS for elementary students: An inquiry into a new approach to learning geography. Journal of Geography, v.98, n.2, p.47-59, 1999.

KERSKI, J. J. The implementation and effectiveness of geographic information systems technology and methods in secondary education. PhD Dissertation. University of Colorado, Boulder, 2000.

. The implementation and effectiveness of geographic information systems technology in secondary education. Journal of Geography, v. 102, n. 3, p. 128-137, 2003.

MACKANESS, W. Curriculum issues in GIS in K-12. Unpublished proceedings from ESRI Users Conference, 1994.

MEYER, J.; BUTTERICK, M.; ZACK, G. GIS in the K-12 curriculum: A cautionary note. Professional Geographer, v. 51, n. 4, p. 571-578, 1999.

PATTERSON, M.; REEVE, K.; PAGE, D. Integrating geographic information systems into the secondary curricula. Journal of Geography, v. 102, n. 6, p. 275-281, 2003.

WALKER, S. GIS and students as scientists: Constructivist approaches to science curriculum restructuring. Geographic Learning Environments Monograph, n. 1, 2004.

WANNER, S. The effectiveness of GIS in high school education. Unpublished proceedings from ESRI Users Conference, 1999.

WANNER, S.; KERSKI, J. The effectiveness of GIS in high school education. 2003. Disponível em: <http://ucsu.colorado.edu/ kerski>. Acesso em: 20 nov. 2005.

WEST, B. Student attitudes and the impact of GIS on thinking skills and motivation. Journal of Geography, v. 102, n. 6, p. 267-274, 2003. 
WHITAKER, D. Using Geographic Information Systems in science classrooms

WINN, J.; MAGGIO, R.; WUNNEBURGER,D. GIS as an educational tool. Unpublished proceedings from ESRI Users Conference, 1996.

Texto recebido em 01 de abril de 2011

Texto aprovado em 20 de abril de 2011. 